\title{
Comentario al libro "Reflexiones sobre Economía desde Nicaragua”, de Rómulo Sánchez
}

Benjamin Bastidas

\section{Universidad de Barcelona}

El profesor Dr. Rómulo Sánchez aborda en su libro "Reflexiones sobre Economía desde Nicaragua" una selección de temas clave relacionados con la globalización. En los siete grandes capítulos de su libro se recorren los rasgos principales de la globalización o mundialización de la economía. Los títulos de los apartados y subapartados son plenamente sugerentes. A lo largo de este recorrido el autor expone sus reflexiones al respecto (de ahí lo adecuado del título de la obra). Los textos contienen no sólo los análisis del autor sino que constituyen por ellos mismos una invitación al lector para que, por un lado, participe en una reflexión conjunta encaminada a desenmascarar la utilización

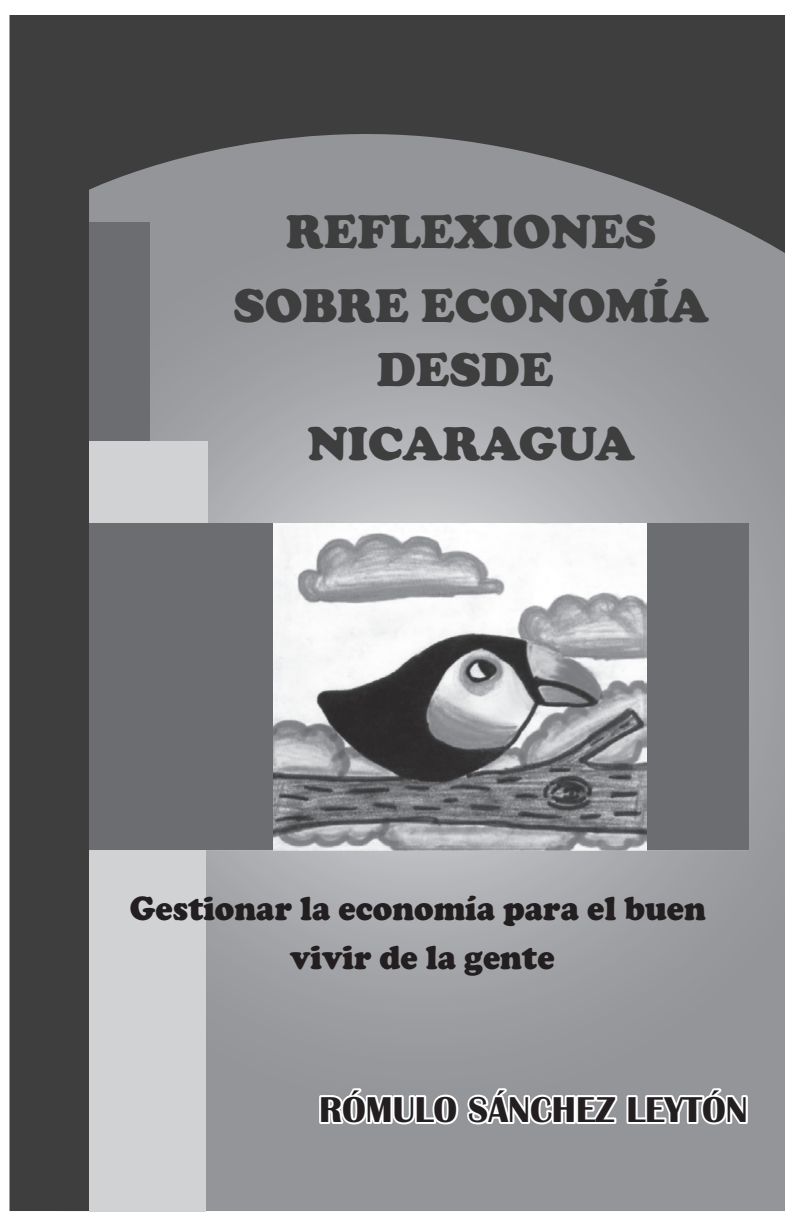


Encuentro No. 95, 99-100, 2013

interesada y excluyente del concepto de globalización y por otro, para que acepte unirse a la búsqueda de otra forma de globalización - de desarrollo humano - capaz de proporcionar autoestima y felicidad para todas y todos.

Me atrevería a decir que éste era y es un libro necesario. Un libro útil y necesario - los mejores calificativos para un libro -. No ofrece el texto una lectura neutra sino provocadora casi en todos sus apartados. Podría decirse que las reflexiones son formuladas con la cabeza pero también con el calor del corazón. El lector se encuentra frente a un pensamiento libre, independiente de los poderes constituidos aquí y allá, que invita continuamente al debate. No es una lectura concluyente, autoritaria o cerrada, en el mal sentido de la palabra, sino abierta a nuevas reflexiones.

A esta sensación contribuye el lenguaje y el tono del texto. La claridad y la organización en la forma de construir cada uno de los capítulos muestra que el autor es un docente con madura experiencia. Pero, posiblemente por esa condición misma, huye de la jerga abstracta de muchos economistas y su lenguaje es fácil e inteligible, salpicado de anécdotas, ejemplos y relevantes contrapuntos al pensamiento único.

Existen en el mercado editorial y en declaraciones oficialistas, textos absolutamente autoritarios, ideológicos, con los que es imposible discutir o no vale la pena intentarlo. Pero en este caso estamos ante un texto inteligente con el que se puede debatir.

En definitiva, considero que la contribución del Dr. Rómulo Sánchez viene a ocupar un puesto relevante al lado de los economistas nicaragüenses preocupados por la dinámica del país. La singularidad de la aportación del profesor de la Facultad de Economía de la UNAN-Managua consiste en colocar acertadamente el análisis de los problemas de la economía nicaragüense en el contexto de la dinámica mundial. Puedo garantizar a los lectores -que previsiblemente serán muchos- una lectura, como decían los antiguos, que "instruye y deleita". Es decir, una lectura amena y provechosa para la reflexión personal. Asimismo, constituirá la obra una excelente contribución a la acción colectiva. 